\title{
IMPLEMENTASI STRATEGI PEMBELAJARAN BERBASIS INKUIRI DENGAN SIKLUS BELAJAR 5E UNTUK MENINGKATKAN KETERAMPILAN BERPIKIR KRITIS
}

\author{
R. Hamidatul Asna \\ email: hamidatul@yahoo.com \\ Guru SMP Negeri 1 Cimahi
}

\begin{abstract}
ABSTRAK
Penelitian ini berawal dari permasalahan pada pembelajaran IPA yang cenderung "content transmission" dan "teacher centered". Pembelajaran demikian mengakibatkan proses penalaran siswa menjadi terbatas. Hal itu mendorong dilakukan penelitian dengan tujuan meningkatkan keterampilan berpikir kritis. Selanjutnya disusun rancangan penelitian strategi pembelajaran berbasis inkuiri dengan siklus belajar 5E untuk meningkatkan keterampilan berpikir kritis. Metode penelitian yang digunakan adalah kuasi eksperimen dengan desain penelitian pretest- postest control group design. Hasil analisis uji hipotesis diperoleh kemampuan berpikir kritis kelompok eksperimen lebih baik dari pada kelompok kontrol setelah pembelajaran. Dengan demikian pembelajaran berbasis inkuiri dengan siklus belajar 5E sangat siginifikan dalam meningkatkan keterampilan berpikir kritis dibandingkan dengan pembelajaran konvensional.
\end{abstract}

Kata kunci: pembelajaran berbasis inkuiri, siklus belajar 5E, berpikir kritis.

\section{ABSTRACT}

This research was started from science's teaching and learning process which inclined to content transmission and teacher-centered condition. This approach has led to students' limitation of intellectual activity process. Furthermore this research designed inquiry based learning strategy with learning cycle (5E) to improve the students' critical thinking skill. The research method which used was quassy experiment with research designpretest and posttest control group design. The result of hypothesis analysis gained from students' thinking skill in experimental group had got better scores than controlled group students'scores. Based on the result, inquiry based learning was very effective to improve students' critical thinking skill rather than conventional learning.

Keywords: teaching and learning based on inquiry, critical thinking, learning cycle (5E).

\section{PENDAHULUAN}

Proses pembelajaran di kelas pada umumnya hanya diarahkan pada kemampuan anak untuk menghafal informasi tanpa melibatkan keterampilan berpikir (Sanjaya, 2008). Demikian pula halnya dengan model dan pendekatan pembelajaran IPA yang masih bersifat menghafal informasi tanpa menuntut pemahaman aplikatif dari dasar teori yang dipelajari ke arah terapannya

Proses pembelajaran di kelas umumnya masih menekankan pada paradigma content transmision atau pemindahan informasi dari guru ke siswa, dengan menerapkan proses pembelajaran yang berpusat pada guru (teacher-centered) dan siswa cenderung pasif, guru menjelaskan materi terkadang dengan bantuan media powerpoint sedangkan siswa hanya berperan sebagai pemerhati saja, pertanyaaan sesekali yang dilontarkan guru tidak direspon baik oleh siswa, hal itu terbukti saat dilakukannnya observasi di salah satu SMP di Kota Cimahi, dengan tidak adanya siswa menjawab secara sukarela namun harus ditunjuk atau diberi giliran oleh guru, jawaban yang diberikan siswa pun cenderung mengulang yang dikatakan oleh guru (recall) dan jika diminta untuk menjawab pertanyaan yang memerlukan alasan, siswa belum mampu menjelaskan kearah sasaran yang ditanyakan. Dengan proses pembelajaran seperti yang dikemukakan di atas siswa hanya menerima materi yang diajarkan, tanpa menelaah lebih dalam dan berkelanjutan sehingga membatasi 
proses berpikirnya.

Proses-proses pembelajaran yang telah di kemukakan di atas tidak selaras dengan tujuan pembelajaran IPA. Standar isi mata pelajaran IPA mengharapkan pendidikan IPA dapat menjadi wahana bagi peserta didik untuk mempelajari diri dan alam sekitar, serta menerapkannya dalam kehidupan seharihari. Proses pembelajaran menekankan pada pemberian pengalaman langsung untuk mengembangkan kompetensi agar menjelajahi dan memahami alam sekitar secara ilmiah. Berdasarkan permendiknas RI no 22 tahun 2006 tentang standar isi untuk satuan pendidikan dasar dan menengah, pembelajaran IPA bertujuan diantaranya agar siswa memiliki kemampuan mengembangkan pemahaman tentang berbagai macam gejala alam, konsep dan prinsip IPA yang bermanfaat dan dapat diterapkan dalam kehidupan sehari-hari. Mengembangkan rasa ingin tahu, sikap positif, dan kesadaran terhadap adanya hubungan yang saling mempengaruhi antara IPA, lingkungan, teknologi, dan masyarakat. Melakukan inkuiri ilmiah untuk menumbuhkan kemampuan berpikir, bersikap dan bertindak ilmiah serta berkomunikasi.

Oleh sebab itu diperlukan proses pembelajaran yang dapat mengembangkan keterampilan berpikir, salah satunya berpikir kritis. Berpikir kritis adalah sebuah keterampilan yang penting pada saat ini, sebab membantu dalam membuat keputusan dan memecahkan masalah (Inch \& Warnick, 2006). Menurut Joane Kurfiss (Inch et al., 2006: 5) berpikir kritis adalah sebagai sebuah pengkajian yang tujuannya adalah untuk mengkaji sebuah situasi, fenomena, pertanyaan atau masalah untuk mendapatkan sebuah hipotesis atau kesimpulan yang mengintegrasikan semua informasi yang tersedia sehingga dapat dijustifikasi dengan yakin. Kemudian gagasan-gagasan lain tentang berpikir kritis selanjutnya banyak dikemukakan oleh para ahli, Epstein (2006: 5) berpendapat bahwa
"Critical thinking is evaluating whether we should be convinced that some claim is true or some argument is good, as well as formulating good argument." Menurut Epstein dalam berpikir kritis diperlukan argumen untuk meyakinkan bahwa sesuatu klaim atau kesimpulan itu adalah benar. Dengan demikian pembelajaran yang menekankan pada proses berpikir dapat mengembangkan keterampilan berpikir kritis siswa sehingga mampu memecahkan masalah dan membuat keputusan dengan benar yang sangat diperlukan dalam menghadapi perubahan zaman.

Richard Paul dan Linda Elder (Inch et al., 2006: 5) menyatakan bahwa pemikiran yang kritis dapat dibagi ke dalam delapan fungsi yang saling berhubungan. Masing-masing fungsi menampilkan sebuah bagian yang penting dari keseluruhan kualitas pemikiran dan hasil. Ada delapan fungsi yang saling berhubungan dan menjadi indikator dalam berpikir kritis, yaitu: (1) Pertanyaan terhadap masalah. Orang melakukan aktivitas berpikir dan menyatakan sesuatu karena adanya kebutuhan; (2) Tujuan. Tujuan menunjukkan adanya hasil yang ingin dicapai oleh seseorang atau apa yang diharapkan akan dicapai; (3) Informasi. Informasi dapat berupa data, fakta,observasi, pengalaman atau sumbersumber lain yang dapat membantu seseorang menjawab pertanyaan; (4) Konsep. Konsep dapat berupa teori, definisi, aturan-aturan dan kaidah-kaidah yang mengatur pemikiran dan tindakan; (5) Asumsi. Asumsi adalah anggapan dasar dan sudut pandang yang kita terima apa adanya; (6) Sudut pandang. Orang-orang menalar dan berpikir dari sudut pandang yang berbeda; (7) Interpretasi dan menarik kesimpulan. Berpikir merupakan proses menggabungkan informasi atau ideide baru kedalam sudut pandang, konsep dan asumsi; dan (8) Implikasi dan akibat-akibat. Penalaran dan berpikir membawa implikasi dan akibat-akibat.

Seiring dengan adanya permasalahan dan 
tuntutan pembelajaran IPA ke arah yang lebih baik, maka salah satu upaya yang dapat dilakukan untuk meningkatkan kualitas pembelajaran IPA adalah memilih desain pembelajaran yang dapat membantu siswa untuk mencapai tujuan pembelajaran. Disain pembelajaran yang mengacu pada teori konstruktivisme sangat cocok untuk mengatasi pembelajaran IPA dewasa ini. Piaget (Rustaman et al., 2003) menyatakan belajar sain merupakan proses konstruktif yang menghendaki partisipasi aktif dari siswa, sehingga peran guru berubah dari sumber dan pemberi informasi menjadi pendiagnosa dan fasilitator belajar siswa.

Salah satu desain pembelajaran yang dapat membangun pengetahuan siswa adalah strategi pembelajaran berbasis inkuiri. Pada strategi pembelajaran inkuiri terdapat suatu rangkaian kegiatan yang melibatkan kemampuan siswa untuk mencari dan menyelidiki secara sistematis, kritis, logis, dan analitis sehingga mereka dapat merumuskan sendiri pengetahuannya dengan rasa percaya diri (Trianto, 2007). National Research Council (1999), menyatakan inkuiri sebagai penggunaan dan pengembangan Higher order thinking pada kegiatan kerja ilmiah. Inkuiri juga merupakan aktivitas eksperimental untuk menguji suatu hipotesis (Joyce et al., 2009). Dimyati (2009) menegaskan bahwa tujuan utama model inkuiri adalah mengembangkan

Tabel 1

Petunjuk pencapaian pembelajaran inkuiri dengan strategi 5E

\begin{tabular}{|c|c|c|}
\hline Tahap & Petunjuk untuk Pencapaiannya & Tujuan Pembelajaran \\
\hline $\begin{array}{l}\text { Engagement } \\
\text { (Melibatkan) }\end{array}$ & $\begin{array}{l}\text { Membuat pengalaman yang berbeda } \\
\text { Mendorong siswa untuk } \\
\text { menyampaikan pengetahuan awal } \\
\text { Mengingat kembali pengetahuan } \\
\text { yang dimiliki siswa } \\
\text { Bertanya } \\
\text { Mendengarkan }\end{array}$ & $\begin{array}{l}\text { Mengembangkan model yang memiliki pandangan } \\
\text { Memahami pengetahuan awal } \\
\text { Menghasilkan pertanyaan }\end{array}$ \\
\hline $\begin{array}{l}\text { Exploration } \\
\text { Menggali }\end{array}$ & $\begin{array}{l}\text { Menyelaraskan pengalaman belajar } \\
\text { siswa untuk menemukan pengetahuan } \\
\text { baru dan mendalam } \\
\text { Bertanya } \\
\text { Berlatih }\end{array}$ & $\begin{array}{l}\text { Memiliki pengetahuan yang mendalam. } \\
\text { Bekerja melalui percobaan } \\
\text { Menemukan pengetahuan baru melalui observasi, } \\
\text { eksperimen, manipulasi } \\
\text { Membuat hubungan } \\
\text { Menghasilkan, mengumpulkan dan mencatat data }\end{array}$ \\
\hline $\begin{array}{l}\text { Explanation } \\
\text { Menjelaskan }\end{array}$ & $\begin{array}{l}\text { Mengemukakan kembali pertanyaan } \\
\text { utama } \\
\text { Proses merespon siswa } \\
\text { Menguatkan respon yang benar } \\
\text { Mengkoreksi miskonsepsi }\end{array}$ & $\begin{array}{l}\text { Menghasilkan model yang mampu menjelaskan } \\
\text { dengan baik } \\
\text { Merespon dengan baik pertanyaan utama } \\
\text { Mengkoreksi miskonsepsi }\end{array}$ \\
\hline $\begin{array}{l}\text { Elaboration } \\
\text { Mengelaborasi }\end{array}$ & $\begin{array}{l}\text { Menciptakan hal yang menantang } \\
\text { bagi siwa untuk menerapkan dan } \\
\text { mentransfer pengetahuan yang baru } \\
\text { diperolehnya. }\end{array}$ & $\begin{array}{l}\text { Memperkuat penjelasan } \\
\text { Menerapkan pengetahuan baru dalam kontes yang } \\
\text { berbeda }\end{array}$ \\
\hline $\begin{array}{l}\text { Evaluation } \\
\text { Menilai }\end{array}$ & $\begin{array}{l}\text { Mengumpulkan umpan balik siswa } \\
\text { Mengidentifikasikan patokan khusus } \\
\text { untuk mengukur kemajuan siswa } \\
\text { menuju pencapaian konsep } \\
\text { Memodifikasi pelajaran dalam } \\
\text { menanggapi umpan balik siswa } \\
\text { Melakukan penilaian sumatif untuk } \\
\text { menilai pembelajaran siswa }\end{array}$ & $\begin{array}{l}\text { Menunjukkan penguasaan pengetahuan baru pada } \\
\text { tingkat nominal, deskriptif dan pemahaman yang } \\
\text { jelas }\end{array}$ \\
\hline
\end{tabular}

(Abruscato dan DeRosa, 2010: 45)

keterampilan intelektual, berpikir kritis dan Untuk mencapai tujuan pembelajaran mampu memecahkan masalah secara ilmiah. 
pembelajarannya, salah satunya adalah melalui siklus belajar 5E. Abruscato dan DeRosa (2010: 44) menjelaskan proses pembelajaran inkuiri dapat dilakukan melalui 5 tahapan pembelajaran yaitu engagement (melibatkan), exploration (menggali), explanation (menjelaskan), elaboration (mengelaborasi), evaluation (menilai) atau dikenal dengan siklus belajar 5E. Berikut ini tabel penjelasan pembelajaran inkuiri dengan menggunakan strategi 5E:

Dari penjelasan di atas, pembelajaran inkuiri melalui siklus belajar $5 \mathrm{E}$ sangat cocok diterapkan untuk mengatasi masalah dalam pembelajaran dewasa ini, karena siswa terlibat aktif untuk mencari dan menyelidiki secara sistematis, kritis, logis, dan analitis sehingga siswa dapat merumuskan sendiri pengetahuannya. Dengan strategi pembelajaran berbasis inkuiri (siklus belajar 5E) siswa dilatih berpikir kritis dan mampu memecahkan masalah secara ilmiah sehingga dapat beradaptasi dalam menghadapi tantangan serta perubahan zaman.

\section{METODE PENELITIAN}

Penelitian ini menggunakan metode eksperimen semu (quassy experiment). Populasi dari penelitian ini adalah siswa kelas VIII di salah satu SMP N di Kota Cimahi. Penarikan sampel dilakukan dengan teknik cluster random sampling yaitu pemilihan sampel berdasarkan kelompok yang sudah ada, karena tidak memungkinkan bagi peneliti untuk mengambil secara acak siswa yang dipilih untuk berpartisipasi dalam penelitian dengan alasan pembatasan administratif (Fraenkel \& Wallen, 2007). Sampel dipilih secara acak sebanyak 2 kelas yaitu siswa kelas VIII A sebanyak 26 orang sebagai kelas eksperimen dan VIII C sebanyak 27 orang sebagai kelas kontrol.

Bentuk desain penelitian yang digunakan adalah "Pretest-Postest Control Group Design” yang ditunjukkan pada Tabel 2.

Tabel 2. Desain kelompok kontrol pretes-postes

\begin{tabular}{|c|c|c|c|}
\hline Kelompok & Pretes & Perlakuan & Postes \\
\hline Eksperimen & $\mathrm{O}$ & $\mathrm{X}_{1}$ & $\mathrm{O}$ \\
\hline Kontrol & $\mathrm{O}$ & $\mathrm{X}_{2}$ & $\mathrm{O}$ \\
\hline
\end{tabular}

Keterangan :

(Fraenkel \& Wallen, 2007)

$\mathrm{O}=$ Instrumen tes tertulis

$\mathrm{X}_{1}=$ Perlakuan berupa startegi pembelajaran inkuiri terbimbing

$\mathrm{X}_{2}=$ Perlakuan berupa strategi pembelajaran langsung (konvensional).

Pada penelitian ini terdiri dari dua kelompok belajar, yaitu kelompok yang diberi perlakuan dengan memberikan strategi pembelajaran berbasis inkuiri terbimbing pada kelompok eksperimen dan strategi pembelajaran langsung (konvesional) pada kelompok kontrol. Kedua kelompok diberikan pretes serta postes yang diharapkan dapat mengukur keterampilan berpikir kritis dan penguasaan konsep sistem peredaran darah sebelum dan sesudah mendapat perlakuan.

Instrumen penelitian yang digunakan untuk mengukur indikator keterampilan berpikir kritis adalah uraian jawaban alasan dari pilihan ganda, atau berupa tes subjektif/ asesmen esay. Asesmen esay sangat potensial untuk mengukur penalaran atau alasan yang dapat menggambarkan keterampilan berpikir kritis. Stiggins (1994) menyatakan guru dapat meminta siswa untuk menganalisis, membandingkan membuat kesimpulan dan atau berpikir kritis secara jelas melalui asesmen penalaran atau asesmen esay.

\section{HASIL DAN PEMBAHASAN}

Hasil penelitian mengenai berpikir kritis siswa pada materi sistem peredaran darah diperoleh dari hasil pretes dan postes. Data 
penelitian nilai pretes dan postes siswa kelas eksperimen dengan kelas kontrol ditampilkan

pada tabel 3 .

Tabel 3. Statistik deskriptif nilai pretes dan postes keterampilan berpikir kritis kelas eksperimen dan kelas kontrol

\begin{tabular}{|c|c|c|c|c|c|c|c|}
\hline \multirow{2}{*}{ Nilai } & \multirow{2}{*}{ Kelas } & \multirow{2}{*}{$\mathrm{N}$} & \multicolumn{4}{|c|}{ Tes Keterampilan Berpikir Kritis Siswa } \\
\cline { 4 - 8 } & & Nilai Ideal & $\begin{array}{c}\text { Nilai } \\
\text { Minimal }\end{array}$ & $\begin{array}{c}\text { Nilai } \\
\text { maksimal }\end{array}$ & Rata-rata & $\begin{array}{c}\text { Standar } \\
\text { deviasi }\end{array}$ \\
\hline \multirow{2}{*}{ Pretes } & Eksperimen & 26 & 100 & 2 & 23 & 7,14 & 4,66 \\
\cline { 2 - 8 } & Kontrol & 27 & 100 & 1 & 16 & 6,8 & 4,44 \\
\hline \multirow{2}{*}{ Postes } & Eksperimen & 26 & 100 & 17 & 74 & 49,40 & 13,98 \\
\cline { 2 - 8 } & Kontrol & 27 & 100 & 12 & 54 & 31,9 & 14,96 \\
\hline
\end{tabular}

Berdasarkan tabel 3, diketahui bahwa ratarata nilai awal siswa kelas eksperimen $(7,14)$ dan kelas kontrol $(6,8)$ terhadap keterampilan berpikir kritis pada sistem peredaran darah hampir sama. Setelah pembelajaran, rata-rata nilai yang diperoleh siswa kelas eksperimen $(49,40)$ dan kelas kontrol $(13,98)$ mengalami peningkatan dan terdapat perbedaan rata-rata nilai kedua kelompok.

Statistik deskriptif rata-rata nilai pretes dan postes kelas eksperimen dan kelas kontrol pada sistem peredaran darah disajikan pada Gambar1.

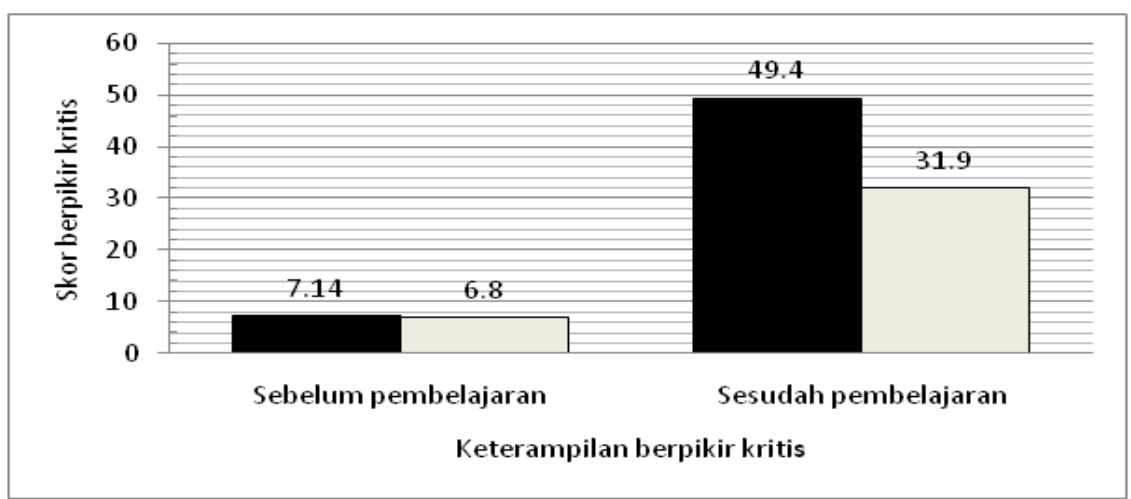

= Kelas eksperimen

Gambar 1. Perbandingan rata-rata nilai berpikir kritis sebelum pembelajaran

$=$ Kelas kontrol dan sesudah pembelajaran pada kelas eksperimen dan kelas kontrol

$=$ Kelas eksperimen

$=$ Kelas kontrol

Untuk mengetahui kategori peningkatan berpikir kritis siswa kelas eksperimen dan kelas kontrol maka dilakukan perhitungan gain ternormalisasi. Hasil perhitungan gain digolongkan atas tiga kategori yaitu kategori tinggi $\mathrm{g}>0,7$, kategori sedang $0,3<\mathrm{g} \leq$
0,7 , dan kategori rendah $\mathrm{g} \leq 0,3$. Persentase peningkatan kemampuan berpikir kritis siswa pada materi sistem peredaran darah berdasakan pada indeks N-gain pretes dan postes untuk kelas eksperimen dan kelas kontrol disajikan pada Tabel 4.

Tabel 4.

Hasil N-gain ternormalisasi berpikir kritis siswa

\begin{tabular}{|c|c|c|c|c|c|}
\hline Data & Kelas & $\begin{array}{c}\text { Sig. } \\
(2 \text {-tailed })\end{array}$ & A & $\begin{array}{c}\text { Penerimaan } \mathrm{H}_{0}(\alpha \\
=0,05)\end{array}$ & Kesimpulan \\
\hline Pretes & $\begin{array}{c}\text { Eksperimen dan } \\
\text { Kontrol }\end{array}$ & 0,858 & 0,05 & Terima $\mathrm{H}_{0}$ & $\begin{array}{c}\text { Tidak ada perbedaan } \\
\text { signifikan }\end{array}$ \\
\hline Postes & $\begin{array}{c}\text { Eksperimen dan } \\
\text { Kontrol }\end{array}$ & 0,000 & 0,05 & Tolak $\mathrm{H}_{0}$ & Berbeda signifikan \\
\hline N-gain & $\begin{array}{c}\text { Eksperimen dan } \\
\text { Kontrol }\end{array}$ & 0,000 & 0,05 & Tolak $\mathrm{H}_{0}$ & Berbeda signifikan \\
\hline
\end{tabular}


Berdasarkan tabel 4. diketahui bahwa peningkatan kemampuan berpikir kritis siswa, untuk kelas eksperimen rata-rata berada pada kategori sedang, sedangkan untuk kelas kontrol rata-rata berada pada kategori rendah. Untuk mengetahui signifikasi perbedaan rata-rata nilai pretes dan postes kelas eksperimen dan kelas kontrol maka data diuji menggunakan uji perbedaan dua rata-rata. Sebelum dilakukan uji perbedaan dua rata-rata, terlebih dahulu dilakukan uji normalitas dan uji homogenitas data pretes, data postes, dan N-gain.

Selanjutnya untuk mengetahui signifikasi perbedaan nilai pretes dan postet serta $\mathrm{N}$-gain kelas kontrol dengan kelas eksperimen, maka data diuji dengan menggunakan uji perbedaan dua rata-rata. Oleh karena data postes dan $\mathrm{N}$-gain berdistribusi normal serta homogen dan jumlah sampel $<30$, maka uji perbedaan rata-rata yang digunakan adalah uji t, sedangkan untuk data pretes meskipun data memiliki varians yang homogen namun data tidak berdistribusi normal maka uji perbedaan rata-rata yang digunakan adalah uji non porametrik yaitu uji Mann Whitney. Pengujian rata-rata nilai pretes, postets dan N-gain dilakukan berdasarkan nilai probabilitas, jika nilai Sig. $<0,05$ maka $\mathrm{H}_{0}$ ditolak.

Tabel 5.

Hasil uji rata-rata berpikir kritis siswa kelas eksperimen, kelas kontrol dan N-gain ternormalisasi

\begin{tabular}{|c|c|c|c|c|c|}
\hline Data & Kelas & $\begin{array}{c}\text { Sig. } \\
(2 \text {-tailed })\end{array}$ & A & $\begin{array}{c}\text { Penerimaan } \mathrm{H}_{0} \\
(\alpha=0,05)\end{array}$ & Kesimpulan \\
\hline Pretes & $\begin{array}{c}\text { Eksperimen } \\
\text { dan Kontrol }\end{array}$ & 0,858 & 0,05 & Terima $\mathrm{H}_{0}$ & $\begin{array}{c}\text { Tidak ada perbedaan } \\
\text { signifikan }\end{array}$ \\
\hline Postes & $\begin{array}{c}\text { Eksperimen } \\
\text { dan Kontrol }\end{array}$ & 0,000 & 0,05 & Tolak $\mathrm{H}_{0}$ & Berbeda signifikan \\
\hline N-gain & $\begin{array}{c}\text { Eksperimen } \\
\text { dan Kontrol }\end{array}$ & 0,000 & 0,05 & Tolak $\mathrm{H}_{0}$ & Berbeda signifikan \\
\hline
\end{tabular}

Berdasarkan data dalam Tabel 5. diperoleh nilai pretes kelompok eksperimen dan kelompok kontrol dari tes kemampuan berpikir kritis nilai Sig. adalah 0,858>0,05 maka $\mathrm{H}_{0}$ diterima, yang berarti bahwa nilai pretes pengetahuan awal siswa pada konsep sistem peredaran darah adalah tidak berbeda signifikan. Hal ini dapat diartikan bahwa kemampuan berpikir kritis awal siswa kelompok eksperimen dan kelompok kontrol relatif sama atau kemampuan berpikir kritis awal siswa kelompok eksperimen dan kelompok kontrol pada materi sistem peredaran darah tidak berbeda signifikan.

Selanjutnya berdasarkan tabel 5 . data postes diperoleh nilai Sig. $0,000<0,05$ maka tolak $\mathrm{H}_{0}$, yang berarti bahwa nilai postes kemampuan berpikir kritis siswa pada konsep sistem peredaran darah adalah berbeda signifikan pada kelas eksperimen dan kelas kontrol. Dengan demikian disimpulkan bahwa $\mathrm{H}_{0}$ ditolak. Hal ini dapat diartikan bahwa nilai kemampuan berpikir kritis kelompok eksperimen setelah pembelajaran lebih baik dari pada kelompok kontrol.

Selanjutnya tabel 5. di atas diperoleh nilai Sig. $0,000<0,05$ maka tolak $\mathrm{H}_{0}$, yang berarti bahwa nilai $\mathrm{N}$-gain kemampuan berpikir kritis siswa pada konsep sistem peredaran darah adalah berbeda signifikan pada kelas eksperimen dan kelas kontrol. Kemampuan berpikir kritis kelompok eksperimen setelah pembelajaran lebih baik dari pada kelompok kontrol.

Kemampuan berpikir kritis yang diukur dalam penelitian ini di fokuskan pada lima 
indikator kemampuan berpikir kritis menurut Paul dan Elder yaitu menggunakan informasi; interpretasi dan menarik kesimpulan; asumsi; konsep dan teori; implikasi dan konsekuensi.
Selisish perolehan skor pretes dan postes untuk setiap indikator keterampilan berpikir kritis dapat dilihat pada Gambar 2.

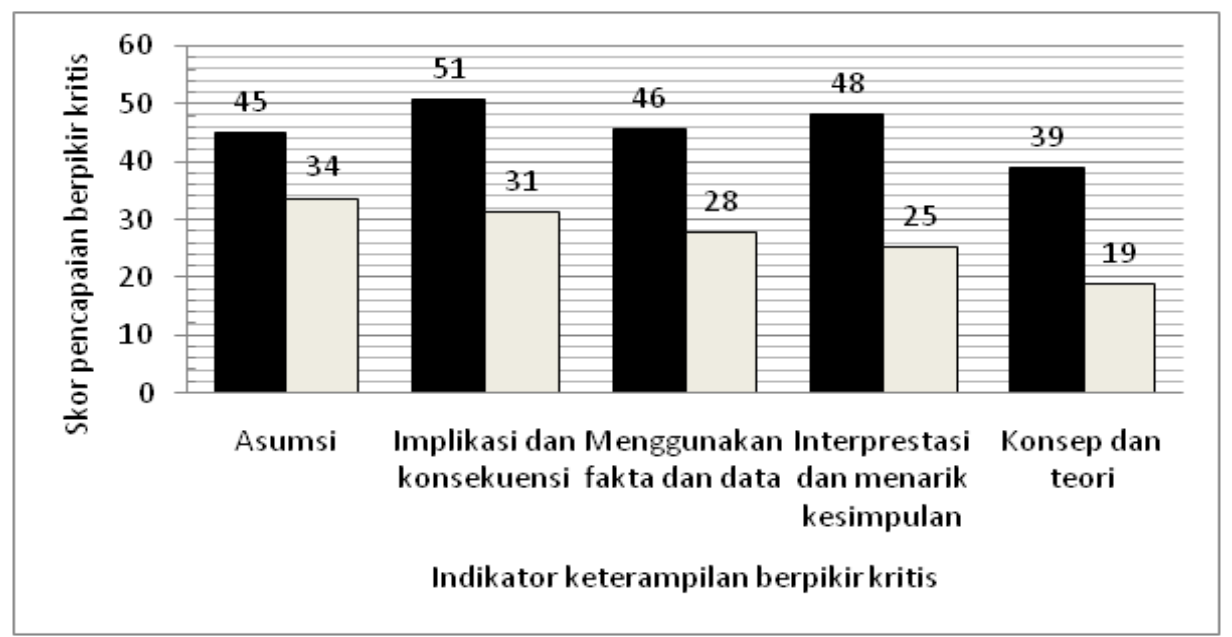

Gambar 2. Kenaikan tiap indikator berpikir kritis di kelas eksperimen dan kelas kontrol $=$ Kelas eksperimen $=$ Kelas kontrol

Berdasarkan tabel 1. dan 2. rata-rata skor pretes kelas eksperimen sebesar 7,14 sedangkan skor postesnya sebesar 49,40, dengan rerata gain skor sebesar 0,46. Adapun rata-rata skor pretes kelas kontrol sebesar 6,8 sedangkan skor postesnya sebesar 31,9 dengan rerata $\mathrm{N}$-gain sebesar 0,27 . Hal ini menunjukkan telah terjadi peningkatan kemampuan berpikir kritis siswa di kedua kelas setelah mengalami pembelajaran, namun peningkatan keterampilan berpikir kritis siswa di kelas eksperimen lebih tinggi dari pada di kelas kontrol. Hasil serupa diperoleh dari penelitian Quitadamo et al. (2008), yang menyatakan bahwa Community-based Inquiry (CBI) membantu meningkatkan kemampuan berpikir kritis dalam pendidikan biologi umum. Hasil analisis penelitian Azizmalareyi et al. (2012) terdapat pengaruh yang signifikan pada metode pembelajaran inkuiri terhadap skor berpikir kritis siswa.

Hasil pengujian hipotesis perbedaan dua rata-rata (uji t) terhadap N-gain diketahui bahwa terdapat perbedaan yang signifikan antara kelompok siswa yang belajar dengan menggunakan strategi pembelajaran berbasis inkuiri dengan strategi pembelajaran langsung (konvensional) terhadap kemampuan berpikir kritis siswa. Hasil pengujian hipotesis tersebut dapat memberikan gambaran bahwa strategi pembelajaran inkuiri memberikan pengaruh yang lebih baik terhadap kemampuan berpikir kritis siswa dibandingkan dengan strategi pembelajaran langsung (konvensional). Pratt \& Heckett (McBride, 2004) menyatakan bahwa dengan belajar IPA melalui inkuiri, siswa mengalami perkembangan pemahaman yang lebih mendalam tentang konsep IPA serta perkembangan dalam keterampilan berpikir kritis.

Pembelajaran materi sistem peredaran darah di kelas eksperimen dilakukan secara berkelompok dengan menggunakan strategi pembelajaran berbasis inkuiri melalui siklus belajar 5E yaitu Engagement (melibatkan), Exploration (menggali), Explanation (menjelaskan), Elaboration (mengelaborasi), Evaluation (mengevaluasi), strategi ini sangat mendukung proses berpikir tingkat tinggi. Dalam tahapan pembelajaran inkuiri dengan strategi ini, diawal pembelajaran siswa dilibatkan secara langsung melalui beberapa pertanyaan atau permasalahan 
yang berhubungan dengan kehidupan sehari-hari. Pada tahap ini pula siswa diberi kesempatan untuk memberikan jawaban sementara dari pertanyaan atau permasalahan tersebut. Tujuan dari tahapan ini mendorong siswa untuk mengenal dan memahami permasalahan atau pertanyaan yang ada apakah permasalahan atau pertanyaan tersebut memerlukan jawaban yang kompleks dan mendalam sebelum mereka berusaha memecahkannya. Paul dan Elder (2005) menyatakan bahwa prinsip dari berpikir kritis adalah "to settle a question", dengan kata lain memahami setiap pertanyaan dan bagaimana cara mencari penyelesaiannya. Hanson (2005) menyatakan bahwa "Critical-thinking questions are the heart of a guided-inquiry learning environment in which students are actively working to learn new content and develop process skills."

Pada tahap explore (menggali) siswa mencari dan menggali sumber informasi yang mendukung kearah pemecahan masalah. Siswa menggali sumber informasi yang ada melalui studi literatur, menyimak audiovisual, mencari sumber data-data yang relevan, melakukan observasi dan eksperimen. Investigasi informasi yang relevan terkait dengan hipotesis yang diajukan akan memberikan kemampuan kepada siswa untuk menemukan sendiri jawabannya dan berpikir secara logis dan rasional yang akan meningkatkan kemampuan berpikir kritisnya. Paul dan Elder (2005) menyatakan bahwa "student who think critically recognize that all thinking is based on some data, information, evidence, experience and research". Siswa yang berpikir secara kritis akan mencari informasi yang relevan dengan pertanyaan dan mencoba untuk menjawab dari permasalahan atau pertanyaan tersebut.

Pada tahap explain (menjelaskan) siswa menjelaskan hasil "temuan" dari tahap sebelumnya sambil mengkoreksi jawaban sementara yang telah dibuat diawal pembelajaran. Pada tahap ini guru melakukan bimbingan untuk memperoleh pemahaman yang mendalam sehingga siswa terhindar dari miskonsepsi. Untuk menjelaskan suatu pertanyaan atau masalah siswa memerlukan kesimpulan (inference) dari informasi yang telah ditemukannya. Tahapan ini melatih berpikir kritis siswa dalam membuat kesimpulan (inference) yang jelas, logis, dapat dibenarkan, dan beralasan dari informasi (temuan) yang diperolehnya, sehingga siswa memperoleh konsep, teori ataupun definisi yang dijadikan landasan dalam berpikir kritis. Paul dan Elder (2005) menyatakan bahwa "student recognize that all thinking contains inferences from which we draw conclusions and give meaning to data and situations." Kerangka penjelasan terdiri dari tiga komponen yaitu klaim (pernyataan atau kesimpulan), bukti, dan alasan/ penalaran, artinya klaim (pernyataan dan kesimpulan) dapat diperoleh melalui data yang beralasan (McNeill, 2011).

Pada tahap elaborate (elaborasi) siswa diberikan permasalahan dengan konteks yang berbeda untuk menerapkan dan mentransfer pengetahuan yang baru diperolehnya, hal ini akan melatih siswa untuk berasumsi dan menggunakan konsep yang telah diperoleh. Paul dan Elder (2005) menyatakan bahwa "student identify the assumption embedded in the concepts they use and the theories they study" "student are able to state, elaborate and exemplify what a concept is."

Bagian terakhir dari strategi 5E Engagement (melibatkan), Exploration (menggali), Explanation (menjelaskan), Elaboration (mengelaborasi) evaluation (evaluasi) adalah tahap evaluasi, pada tahap ini guru memperoleh umpan balik dari pembelajaran yang telah dilakukan. Pada tahap ini siswa sudah menunjukkan penguasaan pengetahuan baru pada tingkat nominal, deskriptif dan 
pemahaman yang jelas, (Abruscato dan DeRosa, 2010).

Berdasarkan penjelasan diatas dapat disimpulkan bahwa strategi pembelajaran berbasis inkuiri melalui siklus belajar 5E sangat membantu dalam meningkatkan keterampilan berpikir kritis, sebab siswa diberi kesempatan untuk mengembangkan keterampilan berpikir kritis disetiap tahap pembelajarannya.

Berbeda halnya pada pembelajaran langsung (konvensional) yang dilakukan di kelas kontrol lebih cenderung teacher centered, artinya dalam proses pembelajaran guru yang berperan paling dominan. Dalam penerapan pembelajaran langsung (konvensional), guru menyajikan informasi tahap demi tahap sedangkan siswa hanya memperhatikan dan menerima apa yang telah disampaikan oleh guru. Guru memberitahu siswa tentang apa yang harus mereka pelajari atau baca, sehingga mengakibatkan pikiran siswa tidak berkembang dengan baik. Hasil pembelajaran yang demikian mengakibatkan siswa hanya terbatas mengingat konsep-konsep dari materi pelajaran yang disampaikan oleh guru tetapi siswa tidak memahami untuk apa konsep tersebut dipelajari.

$\begin{array}{lrr}\text { Strategi pembelajaran } & \text { langsung } \\ \text { (konvensional) } & \text { melibatkan } & \text { banyak }\end{array}$ komunikasi satu arah, sehingga guru sulit untuk mendapatkan umpan balik mengenai pemahaman siswa. Guru mendiktekan informasi dan siswa hanya memperhatikan dan mencatat, sehingga siswa membiasakan diri untuk tidak biasa mengemukakan ide-ide dan memecahkan masalah yang dampaknya akan dibawa anak dalam kehidupan di masyarakat.

\section{KESIMPULAN}

Strategi pembelajaran berbasis inkuiri melalui siklus belajar 5E secara signifikan lebih baik dalam meningkatkan kemampuan berpikir kritis siswa dibandingkan dengan pembelajaran langsung (konvensional) pada materi sistem peredaran darah.

\section{DAFTAR PUSTAKA}

Abruscato, J., and DeRosa D. A.(2010). Teaching Children Science a Discovery Approach (seventh ed.). Boston. Allyn and Bacon.

Epstein, R. L. and Kernberger C. (2006). Critical Thinking (third ed.). Canada: Thomson Wadsworth.

Fraenkel, J. R., \& Wallen, N. E. (2007). How to Design and Evaluate Research in Education (sixth ed). New York: McGraw-Hill.

Inch, E.S., Warnick, B., Endres, D. (2006) Critical Thinking and Communication the Use of Reason in Argument (fifth ed.). United States of America: Pearson.

McBride, J.W, Bhatti,M.I, Hannan, M.A \& Martin Feinberg. (2004). "Using Inquiry Approach to teach Science to Secondary school science Teachers". IOP Journal. 39, (5), 1-6.

McNeill, K.L., Krajcik, J. (2011). Claim, Evidence and Reasoning: Supporting Middle School Students in Evidence Based Scientific Explanations [Online]. Avaliable at: http:// www.katherinelmeneill.com/workshops. $\underline{\mathrm{html}}$ [21 Januari 2014]

Quitadamo, I. J. , Faiola, C.L., Johnson, J. E., Kurtz, M.J. (2008). Community-based Inquiry Improves Critical Thinking in General Education Biology. CBE Life Sci Educ. 7, (3), 327-337.

Rustaman, et al. (2003). Strategi Belajar Mengajar Biologi. Bandung: Universitas Pendidikan Indonesia.

Sanjaya, W. (2008). Strategi Pembelajaran Berorientasi Standar Proses Pendidikan. Jakarta: Kencana Prenada Media Group.

Stiggins, R.J. (1994). Student-Centered Classroom Assessment. NewYork: Macmillan College Publishing Company.

Trianto. (2007). Model-Model Pembelajaran Inovatif Berorientasi Konstruktivisme. Jakarta: Prestasi Pustaka. 